\title{
PENURUNAN MODEL TRAFFIC FLOW BERDASARKAN HUKUM-HUKUM KESETIMBANGAN
}

\author{
Binti Tsamrotul Fitria' ${ }^{\text {, Mohammad Jamhuri² }}$ \\ ${ }^{1}$ Mahasiswa Jurusan Matematika, Fakultas Sains dan Teknologi, UIN Maulana Malik Ibrahim Malang \\ ${ }^{2}$ Dosen jurusan Matematika, Fakultas Sains dan Teknologi, UIN Maulana Maulana Ibrahim Malang \\ E-mail: binti tsamrotulfitria@yahoo.com, m.jamhuri@live.com
}

\begin{abstract}
ABSTRAK
Penelitian ini membahas tentang penurunan model makroskopis masalah traffic flow berdasarkan hukum-hukum kesetimbangan, yaitu hukum kesetimbanganmassa dan hukum kesetimbangan momentum.Asumsi yang digunakan adalah bahwa sepanjang interval jalan tidak ditemukan persimpangan yang menyebabkan perubahan jumlah kendaraan.Langkah-langkah dalam penurunan model persamaan tersebut adalah: (1)menurunkan persamaan kontinuitas dan persamaan momentum sebagai persamaan pengatur, (2) menentukan variabel-variabel yang mempengaruhi traffic flow yaitu kepadatan, kecepatan dan fluks kendaraan, (3) menurunkan model berdasarkan hukum-hukum kesetimbangan tersebut.

Model yang dihasilkan dalam skripsi ini dikenal sebagai persamaan Transport, dimana persamaan tersebut menyatakan kepadatan kendaraan per satuan luas jalan yang dipengaruhi oleh kecepatan. Untuk kecepatan kendaraan yang konstan, maka model tersebut menjadi model linier. Sedangkan bila kecepatan kendaraan bergantung pada kepadatan kendaraan maka persamaan tersebut menjadi non linier. Bentuk non linier dari persamaan traffic flow ini dikenal sebagai persamaan Burger.Solusi dari model yang dihasilkan didapat dengan menggunakan metode finite differenceskema FTBS untuk bentuk yang linier dan menggunakan metode Lax Wendroffskema FTCS untuk bentuk yang non linier.
\end{abstract}

Kata Kunci: traffic flow, model makroskopis, hukum kesetimbangan, metode Lax Wendroff

ABSTRACT
This study discusses the derivation of macroscopic model of traffic flow problems based on the laws of Conservation, those are Conservation law of mass and Conservation law of momentum. The asumtionused is that in the whole of intervals there is no junction which causes the number of vehiclesto change. The steps in the derivation of the equation model are: 1 . Derivingcontinuity equation and momentum equation as the regulator equation, 2. Determining variables which influencetraffic flow, namely density, velocity and flux of vehicle, 3. Deriving model based on the laws of Conservation.

The resulting modelin this thesisis known as the Transport equation, speed of vehicle where, the equation states the vehicle density per unit area which is affected by the speed road. For a constant vehicle speed, the model becomes linear. While, when the speed of the vehicle depends on the density of the vehicle, then the equation becomes nonlinear. Nonlinear form of the traffic flow equation is known as the Burger equation. The solution of the resulting model is obtained by using the method of finite difference implementing FTBS scheme for linear form and using the method of Lax Wendroff implementing FTCS scheme for non-linear form.

Key Words: traffic flow, macroscopic model, the conservation law, Lax Wendroff method.

\section{PENDAHULUAN}

Arus lalu lintas kendaraan masih menjadi masalah yang cukup serius. Kepadatan kendaraan yang terus bertambah membuat kemacetan yang terjadi di kota besar semakin parah, terutama pada ruas jalan yang sempit, bercabang, dan naik turun. Perencanaan dan desain pembangunan jalan sangat penting peranannya dalam pengaturan lalu lintas. Agar terciptanya jalur lalu lintas yang teratur, lancar, dan bebas hambatan sehingga membuat nyaman bagi pengendara maupun penumpang lainnya.

Untuk membangun jalan raya perlu memperhatikan luas jalan yang harus dibangun dan peletakan rambu-rambu lalu lintas atau traffic light. Untuk mengatur tata letak kota tersebut perlu didukung oleh teori traffic flow. Nagel [1] menjelaskan teori traffic flow adalah suatu teori yang membahas masalah transportasi, yang menghubungkan antara tiga variabel fundamental yaitu kecepatan, kepadatan, dan 
flow dari kendaraan itu sendiri. Solusi dari hubungan tersebut, dengan kondisi awal dan masalah batasnya mungkin bisa menjadi informasi yang berguna pada perencanaan dan optimalisasi masalah traffic flow.

Lebih dari setengah abad yang lalu, para ahli Matematika dan teknik telah menggabungkan teori dinamika fluida dengan masalah transportasi. Dimulai pada tahun 1950 an ketika Lighthill dan Witham mengenalkan OneDimensional Method mengenai traffic flow yang menyatakan bahwa masalah transportasi bisa dipelajari dan dimodelkan dengan menggunakan metode dinamika fluida [2]. Sejak saat itu pembahasan mengenai traffic flow menjadi topik yang menarik untuk diteliti sehingga banyak para ilmuwan mengembangkan teori tersebut seperti Daganzo [3] dan Rascle [4] yang mengembangkan model makroskopis dari traffic flow yang telah ditemukan oleh Lighthill dan Whitam [5].

Model dari arus lalu lintas, terbagi menjadi mikroskopis dan makroskopis. Sedangkan Immers dan Logghe [6] menjelaskan bahwa makroskopis adalah pendekatan yang mengamati kendaraan secara keseluruhan dan sangat bergantung pada kepadatan di suatu ruas jalan, sedangkan mikroskopis adalah pendekatan yang mengamati kendaraan secara terpisah, sehingga lebih menekankan pada jarak dan hubungan antar dua kendaraan yang saling berdekatan.

\section{TINJAUAN PUSTAKA}

\section{Persamaan pengatur}

Persamaan pengatur adalah persamaan yang diturunkan melalui hukum-hukum kesetimbangan. Adapun persamaan pengatur dalam penelitian ini adalah:

Persamaan Kontinuitas

Sebuah sistem didefinisikan sebagai kumpulan dari isi yang tidak berubah. Prinsip kekekalan massa berbunyi, laju perubahan massa terhadap waktu sama dengan nol. Olson [7] mengatakan bahwa pada persamaan kontinuitas mensyaratkan bahwa massa fluida harus bersifat kekal, yakni tidak dapat diciptakan atau dimusnahkan.

Bentuk dari persamaan kontinuitas yang diturunkan melalaui hukum kekekalan massa sebagai berikut

$$
\frac{\partial \rho}{\partial t}=-\frac{\partial(\rho u)}{\partial x}-\frac{\partial(\rho v)}{\partial y}-\frac{\partial(\rho w)}{\partial z}
$$

sedangkan

$$
\left[\frac{\partial}{\partial x}, \frac{\partial}{\partial y}, \frac{\partial}{\partial z}\right]=\nabla .
$$

Sehingga persamaan (2.5) di atas dapat ditulis

$$
\frac{\partial \rho}{\partial t}=\rho(\bar{q} \nabla)
$$

\section{a. Persamaan Momentum}

Bentuk dari persamaan momentum yang diturunkan berdasarkan hukum kesetimbangan adalah sebagai berikut

$$
\frac{\partial q}{\partial t}+q \nabla q=-\frac{1}{\rho} \nabla p+g \nabla z
$$

dimana

$$
\begin{gathered}
\bar{q}=(u, v, w) \\
{\left[\frac{1}{\rho} \frac{\partial p}{\partial x}, \frac{1}{\rho} \frac{\partial p}{\partial y}, \frac{1}{\rho} \frac{\partial p}{\partial z}\right]=\frac{1}{\rho}\left(\frac{\partial p}{\partial x}, \frac{\partial p}{\partial y}, \frac{\partial p}{\partial z}\right)=\frac{1}{\rho} \nabla \mathrm{p}} \\
(u, v, w)\left[\frac{\partial u}{\partial x}, \frac{\partial v}{\partial y}, \frac{\partial w}{\partial z}\right]=q \nabla q
\end{gathered}
$$

\section{Variabel Makroskopis}

\section{a. Ukuran Interval}

Interval $\mathrm{S}$ didefinisikan sebagai daerah yang terletak pada ruang $t-x$ seperti yang dijelaskan pada gambar berikut:

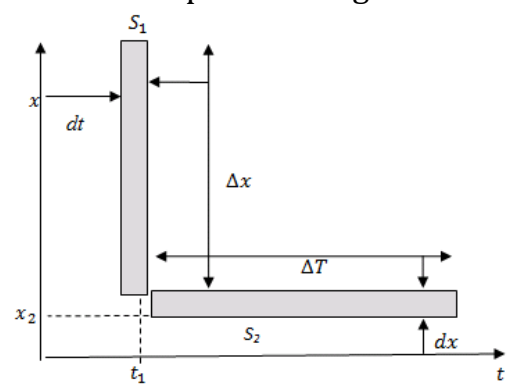

Gambar 1. Ukuran Interval $S_{1}$ dan $S_{2}$

$S_{1}$ merupakan daerah interval tertutup yang berbentuk segiempat ini mewakili ruas jalan sepanjang $\Delta x$ dengan waktu sekecil-kecilnya yaitu $d t . S_{2}$ merupakan daerah segiempat ini mewakili daerah dimana jarak yang sekecilkecilnya dalam waktu yang berbeda. $S_{3}$ adalah ukuran interval yang berubah-ubah sesuai ruang dan waktu. Seperti yang dijelaskan melalui gambar berikut

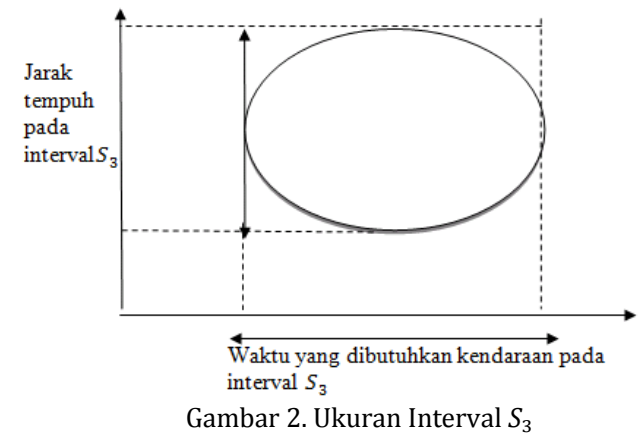

\section{b. Kepadatan Kendaraan}

Kepadatan yang dinotasikan dengan $(\rho)$ menyatakan jumlah kendaraan per kilometernya di jalan (Immers dan Logghe, 2002). Dalam interval satuan waktu tertentu, misalnya daerah 
$S_{1}, \rho$ dapat dicari dengan menghitung banyaknya kendaraan per partisi panjang jalan sebesar $\Delta x$, secara matematis dapat ditulis

$$
\rho=\frac{n}{\Delta x}
$$

dengan $n$ merupakan jumlah kendaraan yang melintas sepanjang interval jalan $\Delta x$.

\section{c. Laju Alir Kendaraan (Fluks)}

Laju alir merupakan jumlah kendaraan yang melintas suatu ruas jalan pada interval waktu tertentu (Immers dan Logghe, 2002). Misalnya pada interval waktu $\Delta T$ dan pada lokasi $x_{2}$ maka laju alirnya bisa dicari dengan

$$
q=\frac{m}{\Delta T}
$$

Indeks $m$ merupakan jumlah kendaraan yang melintas pada lokasi $x_{2}$.

\section{d. Kecepatan}

Kecepatan $v$ adalah hasil bagi antara laju alir dengan kepadatan. Dengan kata lain, kecepatan adalah fungsi atas lokasi, waktu dan ukuran intervalnya [6]. Secara matematis dapat ditulis

$$
v=\frac{q}{\rho}=\frac{\text { total jarak kendaraan di } S_{2}}{\text { total waktu }}
$$

\section{e. Hubungan Antara Ketiga Variabel Makroskopis}

Untuk memberikan gambaran tersebut akan diberikan beberapa kasus di antaranya adalah jika dipunyai pergerakan kendaraan dengan kecepatan konstan $v$ dengan kepadatan $(\rho)$. Karena setiap kendaraan melaju dengan kecepatan yang sama, maka jarak antara masingmasing kendaraan akan menyisakan konstan. Sehingga kepadatan lalu lintas tidak berubah. Untuk mengukur aliran traffic pada saat $t$ jam, kita ingat kembali rumus jarak = kecepatan $\times$ waktu. sehingga pada saat $t$ jam setiap kendaraan akan menempuh jarak $v t$, sehingga jumlah kendaraan yang lewat dan diamati sebanyak $t$ jam merupakan sejumlah kendaraan pada jarak $v t$.

Karena $\rho$ adalah sejumlah kendaraan perkilometer dan jarak sebenarnya berupa $v t$ kilometer, maka $\rho v t$ adalah sejumlah kendaraan yang lewat dan teramati sepanjang $t$ jam. Sehingga sejumlah kendaraan per jam yang disebut aliran lalu lintas $q$ adalah

$$
q=\rho v
$$

Karena variabel lalu lintas bergantung pada jarak dan waktu, maka dapat ditulis

$$
q(x, t)=\rho v
$$

\section{PEMBAHASAN}

\section{Penurunan Model Traffic Flow}

Pada bagian ini akan dijelaskan penurunan model traffic flow berdasarkan hukum-hukum kesetimbangan. Hukum kekekalan massa mensyaratkan bahwa perubahan massa per satuan waktu yaitu perubahan massa terhadap waktu = massa yang masuk - massa yang keluar

Jika $m$ menunjukkan jumlah kendaraan yang melintasi suatu ruas jalan, $\rho$ menunjukkan kepadatan dan $q$ adalah fluks kendaraan, dimana $\left.q\right|_{x}$ menunjukkan fluks kendaraan yang memasuki suatu ruas jalan sedangkan $\left.q\right|_{x+\Delta x}$ adalah fluks kendaraan yang keluar dari ruas jalan maka dapat dinyatakan sebagai

$$
\frac{\partial m}{\partial t}=\left.q\right|_{x}-\left.q\right|_{x+\Delta x}
$$

Berdasarkan rumus dari massa jenis $(\rho)$

$$
\rho=\frac{m}{V}
$$

Untuk $m=$ massa dan $V=$ volume

Sehingga $m=\rho V$

Oleh karena itu persamaan (1) dapat ditulis

$$
\frac{\partial \rho V}{\partial t}=\left.q\right|_{x}-\left.q\right|_{x+\Delta x}
$$

Karena objek pembahasannya adalah jalan raya dan hanya berdimensi satu, maka volume yang dimaksud adalah panjang interval jalan sebesar $\Delta x$. Sehingga persamaan (2) menjadi

$$
\frac{\partial \rho \Delta x}{\partial t}=\left.q\right|_{x}-\left.q\right|_{x+\Delta x}
$$

Dengan membagi kedua ruas dengan $\Delta x$ maka

bila $\Delta x \rightarrow 0$

$$
\frac{\partial \rho}{\partial t}=\frac{\left.q\right|_{x}-\left.q\right|_{x+\Delta x}}{\Delta x}
$$

sehingga

$$
\lim _{\Delta x \rightarrow 0} \frac{\left.q\right|_{x}-\left.q\right|_{x+\Delta x}}{\Delta x}=-\frac{\partial q}{\partial x}
$$

$$
\frac{\partial \rho}{\partial t}=-\frac{\partial q}{\partial x}
$$

karena $q=\rho v$, dimana $v$ adalah kecepatan, maka

atau

$$
\frac{\partial \rho}{\partial t}=-\frac{\partial(\rho v)}{\partial x}
$$

$$
\frac{\partial \rho}{\partial t}+\frac{\partial(\rho v)}{\partial x}=0
$$

\section{Hubungan Kepadatan dengan Kecepatan}

Pada penelitian ini diasumsikan bahwa kepadatan adalah faktor yang paling mempengaruhi kecepatan. Sedangkan untuk faktor lain diabaikan. Sehingga dapat ditulis

$$
v=v(\rho)
$$


Jika tidak terdapat kendaraan lain atau tidak ada mobil lain yang melewati interval $(a, b)$ artinya $\rho=0$ maka kendaraan akan berjalan dengan kecepatan maksimum, yaitu $v_{\text {max }}$, akan tetapi jika terdapat peningkatan kepadatan maka laju kecepatannya menjadi pelan, sehingga dapat ditulis

$$
v(\rho) \leq 0
$$

Sedangkan bila kepadatan kendaraan menjadi maksimum ( $\left.\rho_{\text {maks }}\right)$, maka kondisi jalan menjadi bumper to bumper, dalam keadaan ini kendaraan tidak dapat berjalan atau berhenti. Bila dipaksakan maka kendaraan akan bertabrakan, karena sudah tidak ada ruang lagi untuk bergerak. Sehingga dapat ditulis

$$
\begin{array}{ll} 
& v\left(\rho_{\text {maks }}\right)=0 \\
\text { Sehingga } & \rho_{\text {maks }}=\frac{1}{L} \text { dengan } \mathrm{L} \text { adalah }
\end{array}
$$
panjang kendaraan. Oleh karena itu hubungan antara kepadatan dan kecepatan dapat digambarkan sebagai berikut

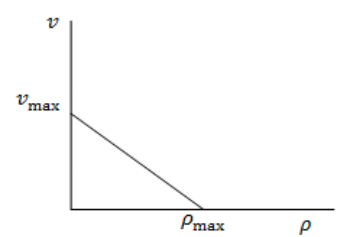

Gambar 3. Hubungan kepadatan dengan kecepatan

Berdasarkan Gambar 3 di atas didapatkan 2 buah titik yaitu $\left(0, v_{\text {maks }}\right)$ dan $\left(\rho_{\text {maks }}, 0\right)$ sehingga bentuk persamaan garisnya dapat dituliskan

$$
\begin{aligned}
& \frac{v-v_{\text {maks }}}{-v_{\text {maks }}}=\frac{\rho-\rho_{\text {maks }}}{\rho_{\text {maks }}} \\
& v=\frac{-\rho v_{\text {maks }}}{\rho_{\text {maks }}}+v_{\text {maks }} \\
& v=v_{\text {maks }}\left(1-\frac{\rho}{\rho_{\text {maks }}}\right)
\end{aligned}
$$

Ansgar Jungel [8] menyatakan model kecepatan yang bergantung kepadatan dalam bentuk persamaan

$$
\begin{aligned}
& v(\rho)=v_{\text {maks }}\left(1-\frac{\rho}{\rho_{\text {maks }}}\right), \quad 0 \leq \\
& \rho \leq \rho_{\text {maks }}
\end{aligned}
$$

Kemudian persamaan (4) disubstitusikan pada model traffic flow pada persamaan (4.3) menjadi

$$
\begin{aligned}
\rho_{t}+\left[v_{\text {maks }} \rho\left(1-\frac{\rho}{\rho_{\text {maks }}}\right)\right]_{x}=0 \\
\rho_{t}+\left[v_{\text {maks }} \rho-\frac{v_{\text {maks }}}{\rho_{\text {maks }}} \rho^{2}\right]_{x}=0
\end{aligned}
$$

Dengan mensubstitusikan data-data yang sudah didapatkan bisa ditentukan suatu persamaan garis lurus yang menggambarkan hubungan antar kecepatan dengan kepadatan lalu lintasnya.

Observasi yang dilakukan menghasilkan data $v_{\max }=27.8 \mathrm{~m} / \mathrm{dt}$ pada saat kepadatan mendekati 0 , sedangkan $v \approx 0$ pada saat $\rho_{\max }=$ 0.67 . Sehingga didapatkan 2 titik $(0, v)$ dan $(\rho, 0)$ yaitu $(0,27.89)$ dan $(0.67,0)$.

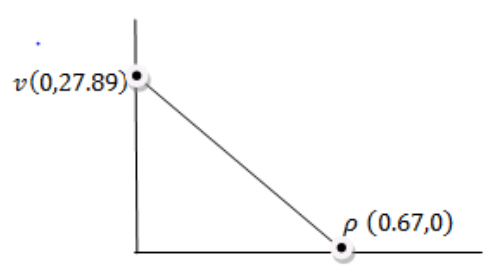

Gambar 4. Persamaan Garis

dengan mensubstitusikan data di atas ke persamaan (4) maka didapatkan

$$
\begin{gathered}
v(\rho)=v_{\text {maks }}\left(1-\frac{\rho}{\rho_{\text {maks }}}\right) \\
v(\rho)=27.89\left(1-\frac{\rho}{0.67}\right)
\end{gathered}
$$

\section{Penskalaan}

Skala adalah perbandingan ukuran pada model dengan ukuran sebenarnya. Baik mengubah ke ukuran yang lebih kecil, maupun ke ukuran yang lebih besar dengan tanpa menghilangkan karakteristiknya. Selanjutnya kita kenalkan variabel lain dengan mengikuti penelitian sebelumnya [8] yaitu $\theta$ dan $\tau$ dimana $\theta$ menyatakan jarak dan $\tau$ waktu, bila $\frac{\theta}{\tau}=v_{\text {maks }}$ maka akan ada $x_{s}=\frac{x}{\theta}, t_{s}=\frac{t}{\tau}$ dan $u=1-\frac{2 \rho}{\rho_{\text {maks }}}$

sehingga

$$
\rho_{t}=\frac{\partial \rho}{\partial t_{s}} \cdot \frac{\partial t_{s}}{\partial t}
$$

karena $u=1-\frac{2 \rho}{\rho_{\text {maks }}}$ Maka $\rho=\frac{\rho_{\text {maks }}}{2}(1-u)$ sehingga

$$
\begin{aligned}
\rho_{t} & =\left[\frac{\rho_{\text {maks }}}{2}(1-u)\right]_{t_{s}} \frac{1}{\tau} \\
\rho_{t} & =\frac{1}{\tau}\left[\frac{\rho_{\text {maks }}}{2}(1-u)\right]_{t_{s}} \\
\rho_{t} & =-\frac{\rho_{\text {maks }}}{2 \tau} u_{t_{s}}
\end{aligned}
$$

sedangkan untuk 


$$
\begin{gathered}
\rho_{x}=\frac{\partial \rho}{\partial x_{s}} \cdot \frac{\partial x_{s}}{\partial x} \\
\rho_{x}=\left[\frac{\rho_{\text {maks }}}{2}(1-u)\right]_{x_{s}} \frac{1}{\theta} \\
\rho_{x}=\frac{1}{\theta}\left[\frac{\rho_{\text {maks }}}{2}(1-u)\right]_{x_{s}} \\
\rho_{x}=-\frac{\rho_{\text {maks }}}{2 \theta} u_{x_{s}}
\end{gathered}
$$

Selanjutnya dengan mensubstitusikan persamaan (6) dan (7) ke persamaan (5) maka

$$
\begin{aligned}
& \rho_{t}+\left[v_{\text {maks }} \rho-\frac{v_{\text {maks }}}{\rho_{\text {maks }}} \rho^{2}\right]_{x}=0 \\
& \rho_{t}+v_{\text {maks }} \rho_{\mathrm{x}}-\frac{v_{\text {maks }}}{\rho_{\text {maks }}}\left(2 \rho \rho_{\mathrm{x}}\right)=0 \\
& -\frac{\rho_{\text {maks }}}{2 \tau} u_{t_{s}}+v_{\text {maks }}\left(-\frac{\rho_{\text {maks }}}{2 \theta} u_{x_{s}}\right)- \\
& \frac{v_{\text {maks }}}{\rho_{\text {maks }}}\left(2\left(\frac{\rho_{\text {maks }}}{2}(1-u)\right)\left(-\frac{\rho_{\text {maks }}}{2 \theta} u_{x_{s}}\right)\right)=0 \\
& -\frac{\rho_{\text {maks }}}{2 \tau} u_{t_{s}}+v_{\text {maks }}\left(-\frac{\rho_{\text {maks }}}{2 \theta} u_{x_{s}}\right)+\quad=0 \\
& v_{\text {maks }} \frac{\rho_{\text {maks }}}{2 \theta}\left((1-u) u_{x_{s}}\right) \\
& \text { Karena } \frac{\theta}{\tau}=v_{\text {maks }} \text { maka } \\
& \begin{array}{c}
-\frac{\rho_{\text {maks }}}{2 \tau} u_{t_{s}}-\frac{\theta}{\tau} \frac{\rho_{\text {maks }}}{2 \theta}\left(u_{x_{s}}-u_{x_{s}}+u u_{x_{s}}\right) \\
=0 \\
-\frac{\rho_{\text {maks }}}{2 \tau} u_{t_{s}}-\frac{\rho_{\text {maks }}}{2 \tau}\left(u u_{x_{s}}\right)=0
\end{array}
\end{aligned}
$$

Bila kedua ruas dibagi dengan $-\frac{\rho_{\text {maks }}}{2 \tau}$ maka menjadi

$$
u_{t_{s}}+u u_{x_{s}}=0
$$

Model tersebut dikenal sebagai model traffic flow. Untuk selanjutnya $t_{s}$ akan ditulis sebagai $t$ dan $x_{s}$ akan ditulis sebagai $x$.Sehingga modelnya menjadi

$$
u_{t}+u u_{x}=0
$$

\section{Solusi dan Simulasi}

\section{a. Model Linier dari Persamaan Traffic Flow}

Pada persamaan (3) bila $v(\rho)$ merupakan suatu konstanta maka persamaan tersebut menjadi persamaan transport linier. Sehingga persamaan (3) dapat dituliskan

$$
\frac{\partial \rho}{\partial t}+v \frac{\partial \rho}{\partial x}=0
$$

dengan

$$
\begin{gathered}
\rho(0, t)=3 \\
\rho(1680, t)=2 \\
\rho(x, 0)=\frac{-x}{1680}+3
\end{gathered}
$$

Kondisi awal $\rho$ diperoleh dengan mengasumsikan jarak $x$ berada pada selang interval $(0,1680)$ yang akan didapatkan suatu persamaan garis lurus yang menghubungkan $\rho$ di batas kiri dengan $\rho$ di batas kanan. Melalui rumus persamaan garis lurus akan didapatkan

$$
\begin{gathered}
\frac{\rho-3}{2-3}=\frac{x}{1680} \\
(\rho-3)=\frac{x}{1680}(-1) \\
\rho=\frac{-x}{1680}+3
\end{gathered}
$$

Dengan menggunakan metode beda hingga skema FTBS (forward time backward space) yaitu aproksimasi dengan menggunakan skema beda maju untuk waktu dan skema beda mundur untuk ruang, maka akan diperoleh bentuk diskrit seperti berikut

$$
\begin{aligned}
& \rho_{t}=\frac{\rho_{j}^{n+1}-\rho_{j}^{n}}{\Delta t} \\
& \rho_{x}=\frac{\rho_{j}^{n}-\rho_{j-1}^{n}}{\Delta x}
\end{aligned}
$$

sehingga persamaan (9) menjadi

$$
\begin{aligned}
& \frac{\rho_{j}^{n+1}-\rho_{j}^{n}}{\Delta t}+v \frac{\rho_{j}^{n}-\rho_{j-1}^{n}}{\Delta x}=0 \\
\rho_{j}^{n+1} & =\rho_{j}^{n}-v \frac{\Delta t}{\Delta x}\left[\rho_{j}^{n}-\rho_{j-1}^{n}\right]
\end{aligned}
$$

Selanjutnya akan dilakukan simulasi dari persamaan (10), dengan menggunakan program MATLAB. Dengan mengambil $\Delta x=0.99 \mathrm{~m}$ dan $\Delta t=0.099$ satuan waktu, dan mengambil $v=$ $3 \mathrm{~m}$ per satuan waktu. Sehingga perubahan kepadatan kendaraan dapat dilihat sebagai berikut

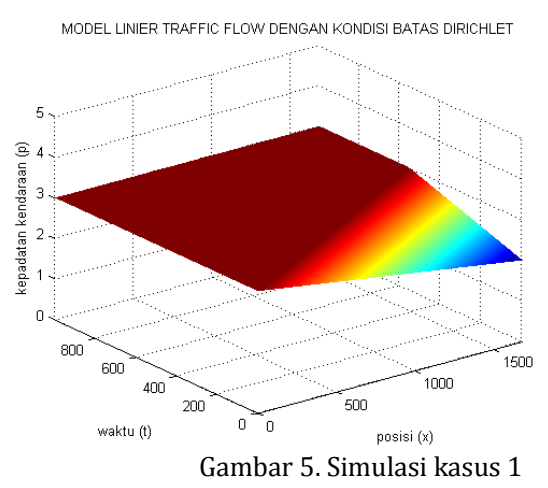

Dari Gambar 5 di atas dapat dilihat bahwa sepanjang waktu $t$ pada batas kiri kepadatannya sebesar 3 kendaraan per satuan luas dan pada batas kanan kepadatannya 2 kendaraan per 
satuan luas. Hal ini menunjukkan bahwa pada posisi $x=0$ selalu terdapat 3 kendaraan, dan pada posisi $x=1680$ selalu terdapat 2 kendaraan. Sedangkan untuk mengetahui kondisi kepadatan di setiap posisi $x$ pada saat $t$ tertentu maka digambarkan pada grafik berikut
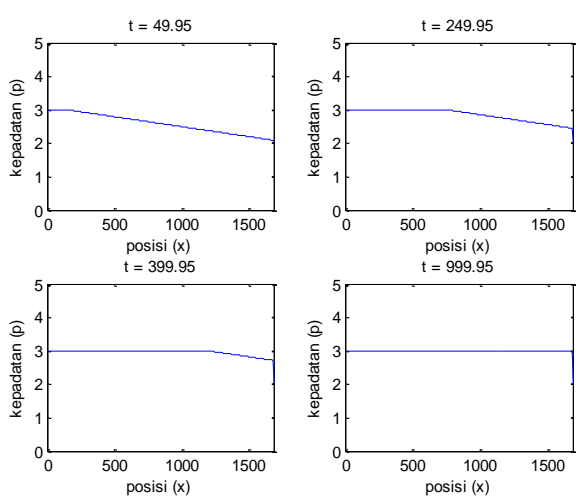

Gambar 6. Simulasi Kasus 1 dengan Waktu Berbeda

Berdasarkan gambar 6 tersebut dapat diketahui bahwa pada saat $t=0$ kepadatan kendaraan sebesar 2 kendaraan per satuan luas, setelah $t=49.95$ kendaraan mulai bertambah. Karena jumlah kendaraan di batas kiri lebih banyak daripada batas kanan, sehingga kendaraan menumpuk di titik-titik awal. Dan untuk $t$ menuju tak hingga kepadatan di sepanjang jalan besarnya sama, yaitu 3 kendaraan per satuan luasnya, tetapi di ujung jalan tetap ada 2 kendaraan per satuan luasnya.

Simulasi pada kasus kedua, bila diasumsikan bahwa kepadatan kendaraan di daerah batas berkebalikan dengan kasus pertama. Jika terdapat 2 kendaraan di batas kiri dan terdapat 3 kendaraan maka dengan melakukan hal yang sama akan didapat grafik kepadatannya sebagai berikut

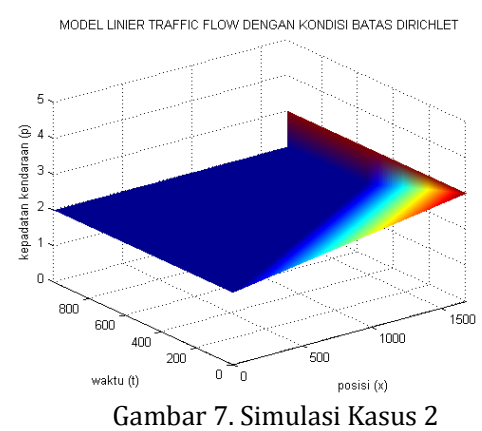

Pada kasus kedua ini, kepadatan kendaraan di batas kiri sebanyak 2 kendaraan per satuan luas, sedangkan kepadatan di batas kanan sebanyak 3 kendaraan per satuan luas, sehingga dapat diketahui bahwa penumpukan kendaraan terjadi di ujung interval yang akan berdampak pada kemacetan. Tetapi setelah $t=$ 1000 kondisi jalan telah mencapai kepadatan yang seimbang, artinya, sepanjang jalan kepadatannya sama; yaitu 2 kendaraan per satuan luas jalan. Seperti yang ditunjukkan pada gambar berikut
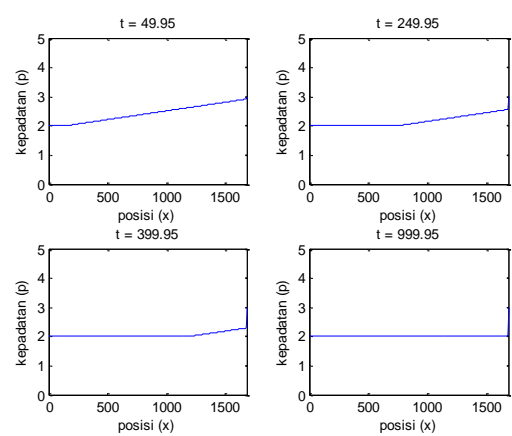

Gambar 8. Simulasi Kasus 2 dengan Waktu Berbeda

Selanjutnya dengan menggunakan metode karakteristik bisa didapatkan solusi analitik dari model linier

$$
\begin{gathered}
\frac{\partial \rho}{\partial t}+v \frac{\partial \rho}{\partial \underline{x}}=0 \\
\rho(x, 0)=\frac{-x}{1680}+3
\end{gathered}
$$

Persamaan $\frac{\partial \rho}{\partial t}+v \frac{\partial \rho}{\partial x}=0$ adalah turunan berarah dari $\rho$ dalam suatu vektor dengan arah $\mathbb{V}=$ $[1, v]=i+v j$ dimana kurva dari persamaan tersebut memiliki gradien

$$
\frac{d x}{d t}=\frac{v}{1}=v
$$

Dalam hal ini selalu bernilai 0 atau $\rho(x, t)=c$ dalam arah $\mathbb{V}$. Vektor $[v,-1]$ adalah orthogonal terhadap $\mathbb{V}$. Sedangkan garis yang sejajar dengan $\mathbb{V}$ adalah $-x=c$, dan persamaan ini disebut persamaan karakteristik. Solusi PDP di atas selalu konstan dalam masing-masing karakteristik ini, sehingga tergantung hanya pada $v t-x$. Dengan demikian solusinya adalah

$$
\rho(x, t)=f(v t-x)
$$

Atau bisa dengan menggunakan metode koordinat. Dalam sistem koordinat $t, x$ dapat kita transportasikan ke dalam sistem

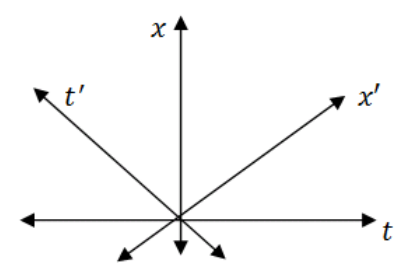

Gambar 9. Transportasi Sistem Koordinat

Misal ditetapkan $t^{\prime}=t+v x$ dan $x^{\prime}=$ $v t-x$ dengan aturan turunan rantai maka turunan $\rho\left(x^{\prime}, y^{\prime}\right)$ terhadap $x$ dan $y$ adalah 


$$
\begin{gathered}
\rho_{t}=\frac{\partial \rho}{\partial t}=\frac{\partial \rho}{\partial t^{\prime}} \cdot \frac{\partial t^{\prime}}{\partial t}+\frac{\partial \rho}{\partial x^{\prime}} \cdot \frac{\partial x^{\prime}}{\partial t}=\rho_{t^{\prime}}+v \rho_{x^{\prime}} \\
\rho_{x}=\frac{\partial \rho}{\partial x}=\frac{\partial \rho}{\partial x^{\prime}} \cdot \frac{\partial x^{\prime}}{\partial x}+\frac{\partial \rho}{\partial t^{\prime}} \cdot \frac{\partial t^{\prime}}{\partial x}=-\rho_{x^{\prime}}+v \rho_{t^{\prime}} \\
=v \rho_{t^{\prime}}-\rho_{x^{\prime}}
\end{gathered}
$$

Selanjutnya substitusikan ke dalam persamaan $\frac{\partial \rho}{\partial t}+v \frac{\partial \rho}{\partial x}=0$ sehingga

$$
\begin{gathered}
\rho_{t^{\prime}}+v \rho_{x^{\prime}}+v\left(v \rho_{t^{\prime}}-\rho_{x^{\prime}}\right)=0 \\
\rho_{t^{\prime}}+v \rho_{x^{\prime}}+v^{2} \rho_{t^{\prime}}-v \rho_{x^{\prime}}=0 \\
\rho_{t^{\prime}}+v^{2} \rho_{t^{\prime}}=0 \\
\left(1+v^{2}\right) \rho_{t^{\prime}}=0
\end{gathered}
$$

untuk $\left(1+v^{2}\right) \neq 0$ maka

$$
\begin{aligned}
\rho_{t^{\prime}} & =0 \\
\int \rho_{t^{\prime}} d t^{\prime} & =\int 0 d t^{\prime} \\
\rho(x, t) & =f\left(x^{\prime}\right)
\end{aligned}
$$

sehingga $\rho(x, t)=f(v t-x)$ merupakan solusi analitiknya.

Dengan mensubstitusikan nilai awal ke model (9) sedangkan untuk $v=3$ maka

sehingga

$$
\begin{gathered}
\rho(x, 0)=f(3.0-x) \\
\rho(x, 0)=f(-x) \\
f(-x)=\frac{-x}{1680}+3
\end{gathered}
$$

maka solusi analitiknya

$$
f(3 t-x)=\frac{(3 t-x)}{1680}+3
$$

$$
\begin{aligned}
& \rho(x, t)=\frac{(3 t-x)}{1680}+3 \\
& \rho(x, t)=\frac{(3 t-x)}{1680}+3
\end{aligned}
$$

Solusi analitik digunakan untuk membandingkan keakuratan dari metode numerik yang dipakai dalam skripsi ini. Untuk mengetahui galat pada solusi numerik dari model linier tersebut akan dilakukan simulasi dengan mengambil domain $0<x<1$ dan $0<t<1$ dengan $\Delta x=\Delta t=025$. Sedangkan untuk solusi numeriknya yaitu persamaan (10) dengan kondisi batasnya

$$
\begin{gathered}
\rho_{j}^{n+1}=\rho_{j}^{n}-v \frac{\Delta t}{\Delta x}\left[\rho_{j}^{n}-\rho_{j-1}^{n}\right] \\
\rho(0, t)=\frac{3 t}{1680}+3 \\
\rho(1, t)=\frac{3 t-1}{1680}+3
\end{gathered}
$$

Maka didapatkan solusi sebagai berikut:

\begin{tabular}{ccccc}
\multicolumn{5}{c}{ Tabel 1. Perbandingan Solusi Analitik dan Solusi Numerik } \\
\hline $\mathrm{x}$ & $\mathrm{T}$ & Analitik & Numerik & galat \\
\hline 0 & 0 & 3.0000 & 3.0000 & 0 \\
0 & 0.25 & 3.0004 & 3.0004 & 0 \\
0 & 0.5 & 3.0009 & 3.0009 & 0 \\
0 & 0.75 & 3.0013 & 3.0013 & 0 \\
\hline
\end{tabular}

\begin{tabular}{ccccc}
\hline 0 & 1 & 3.0018 & 3.0018 & 0 \\
0.25 & 0 & 2.9999 & 2.9999 & 0 \\
0.25 & 0.25 & 3.0003 & 3.0003 & 0 \\
0.25 & 0.5 & 3.0007 & 3.0007 & $0.0444 \times 10^{-14}$ \\
0.25 & 0.75 & 3.0012 & 3.0012 & $-0.0888 \times 10^{-14}$ \\
0.25 & 1 & 3.0016 & 3.0016 & $0.1776 \times 10^{-14}$ \\
0.5 & 0 & 2.9997 & 2.9997 & 0 \\
0.5 & 0.25 & 3.0001 & 3.0001 & 0 \\
0.5 & 05 & 3.0006 & 3.0006 & 0 \\
0.5 & 0.75 & 3.0010 & 3.0010 & $0.0444 \times 10^{-14}$ \\
0.5 & 1 & 3.0015 & 3.0015 & $-0.3553 \times 10^{-14}$ \\
0.75 & 0 & 2.9996 & 2.9996 & 0 \\
0.75 & 0.25 & 3.0000 & 3.0000 & 0 \\
0.75 & 0.5 & 3.0004 & 3.0004 & 0 \\
0.75 & 0.75 & 3.0009 & 3.0009 & $0.0444 \times 10^{-14}$ \\
0.75 & 1 & 3.0013 & 3.0013 & $0.0444 \times 10^{-14}$ \\
1 & 0 & 2.9994 & 2.9994 & 0 \\
1 & 0.25 & 2.9999 & 2.9999 & 0 \\
1 & 0.5 & 3.0003 & 3.0003 & 0 \\
1 & 0.75 & 3.0007 & 3.0007 & 0 \\
1 & 1 & 3.0012 & 3.0012 & 0 \\
\hline
\end{tabular}

Dari hasil solusi di atas dapat diketahui bahwa galat maksimumnya sebesar $0.1776 \times 10^{-}$ 14 pada saat $x=0.25$ dan $t=1$. Sedangkan untuk yang lain galatnya sangat kecil bahkan hampir keseluruhan galatnya 0 . Hal ini bisa dikatakan bahwa metode FTBS ini sudah cukup baik untuk mengaproksimasi model tersebut. Adapun untuk grafik solusi bisa dilihat di bawah ini

Table 2. Grafik Solusi untuk Solusi Analitik dan Numerik

\begin{tabular}{|c|c|}
\hline Solusi analitik & Solusi numerik \\
\hline &
\end{tabular}

\section{b. Model Non Linier Persamaan Traffic Flow}

Pada persamaan (3) di atas jika kecepatannya bergantung pada kepadatan kendaraan yang berbeda di setiap posisi, maka persamaan tersebut menjadi persamaan non linier. Persamaan (10) adalah persamaan (3) yang telah diskalakan sehingga menjadi persamaan Burger.

Misal diasumsikan pada batas interval $(0,1680)$ adalah $x=0$ batasnya 3 kendaraan dan $x=1680$ batasnya 2 kendaraan. Artinya pada posisi $x=0$ selalu terdapat 3 kendaraan per satuan luas. Dan pada posisi $x=1680$ selalu terdapat 2 kendaraan per satuan luas. Persamaan (10) beserta kondisi batasnya dapat dituliskan sebagai berikut

$$
\begin{aligned}
& u_{t}+u u_{x}=0 \\
& t>0 \text { dan } 0<x<1680
\end{aligned}
$$

dengan

$$
\begin{aligned}
& u(0, t)=3 \\
& u(1680, t)=2
\end{aligned}
$$




$$
u(x, 0)=\frac{-x}{1680}+3
$$

Selanjutnya akan dilakukan pendiskritan pada persamaan (10) tersebut dengan menggunakan metode Lax Wendroff skema FTCS (forward time center space) dengan mensubstitusikan $u_{t}$ ke bentuk $u_{x}$. Sehingga bentuk diskritnya sebagai berikut

$$
\begin{gathered}
u_{t}+u u_{x}=0 \\
u_{t}=-u u_{x} \\
u_{t t}=-\left(u u_{x}\right)_{t} \\
u_{t t}=-u_{t} u_{x}-u u_{x t}
\end{gathered}
$$

Berdasarkan ekspansi Taylor

\begin{tabular}{|l|l|}
$u_{j}^{n+1}=U_{j}^{n}+\left.\Delta t u_{t}\right|_{j} ^{n}+\left.\frac{1}{2} \Delta t^{2} u_{t t}\right|_{j} ^{n}+\cdots$ \\
\hline$u_{j}^{n+1}=\mid$\begin{tabular}{l|l}
$u_{j}^{n}+\left.\Delta t\left(-u u_{x}\right)\right|_{j} ^{n}+$ \\
$\left.\frac{1}{2} \Delta t^{2}\left(-u_{t} u_{x}-u u_{x t}\right)\right|_{j} ^{n}$
\end{tabular} \\
\hline
\end{tabular}

Karena pada persamaan (11) ruas kanan masih terdapat unsur $u_{t}$ maka

$$
\begin{aligned}
\left(-u_{t} u_{x}-u u_{x t}\right) & =\left(-\left(-u u_{x}\right) u_{x}\right)-u u_{x t} \\
& =\left(u u_{x}\right) u_{x}-u\left(u_{t}\right)_{x} \\
& =u\left(u_{x}\right)^{2}-u\left(-u u_{x}\right)_{x} \\
& =u\left(u_{x}\right)^{2}+u\left(u_{x} u_{x}+u u_{x x}\right) \\
& =u\left(u_{x}\right)^{2}+u\left(u_{x}\right)^{2}+u^{2} u_{x x} \\
& =2 u\left(u_{x}\right)^{2}+u^{2} u_{x x}
\end{aligned}
$$

Selanjutnya substitusi persamaan (11) ke persamaan (12)

$$
\begin{aligned}
u_{j}^{n+1}= & u+\left.\Delta t\left(-u u_{x}\right)\right|_{j} ^{n} \\
& +\left.\frac{1}{2} \Delta t^{2}\left(2 \cdot u\left(u_{x}\right)^{2}+u^{2} u_{x x}\right)\right|_{j} ^{n} \\
u_{j}^{n+1}= & u_{j}^{n}-\left.\Delta t\left(u u_{x}\right)\right|_{j} ^{n} \\
& +\left.\Delta t^{2}\left(u\left(u_{x}\right)^{2}+\frac{1}{2} u^{2} u_{x x}\right)\right|_{j} ^{n} \\
u_{j}^{n+1} & =u_{j}^{n}-\Delta t\left(u_{j}^{n}\left[\frac{u_{j+1}^{n}-u_{j-1}^{n}}{2 \Delta x}\right]\right) \\
& +\Delta t^{2}\left(u_{j}^{n}\left[\frac{u_{j+1}^{n}-u_{j-1}^{n}}{2 \Delta x}\right]^{2}\right. \\
& \left.+\frac{1}{2} u^{2}\left[\frac{u_{j+1}^{n}-2 u_{j}^{n}+u_{j-1}^{n}}{\Delta x^{2}}\right]\right)
\end{aligned}
$$$$
u_{j}^{n+1}=u_{j}^{n}-\frac{\Delta t}{2 \Delta x}\left(u_{j}^{n}\left[u_{j+1}^{n}-u_{j-1}^{n}\right]\right)+
$$$$
\frac{\Delta t^{2}}{4 \Delta x^{2}}\left(u_{j}^{n}\left[u_{j+1}^{n}-u_{j-1}^{n}\right]^{2}\right)+
$$$$
\frac{\Delta t^{2}}{2 \Delta x^{2}}\left(\left(u_{j}^{n}\right)^{2}\left[u_{j+1}^{n}-2 u_{j}^{n}+u_{j-1}^{n}\right]\right)
$$

Selanjutnya pada kasus ketiga ini akan dilakukan simulasi untuk model non linier dengan kondisi batas dirichlet. Dengan mengambil $\Delta x$ dan $\Delta t$ sama seperti kasus sebelumnya maka kepadatan kendaraan pada kasus ini dapat dilihat sebagai berikut

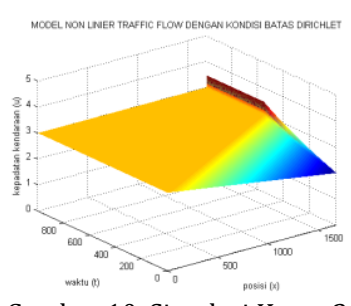

Gambar 10. Simulasi Kasus 3

Dari Gambar 10 dapat dilihat bahwa pada batas kiri kepadatannya sebesar 3 dan pada batas kanan kepadatannya 2. Gambar tersebut menunjukkan hubungan antara kepadatan berdasarkan ruang dan waktu. Sedangkan untuk mengamati perubahan kepadatan di tiap waktu tertentu maka disajikan dalam bentuk plot berikut
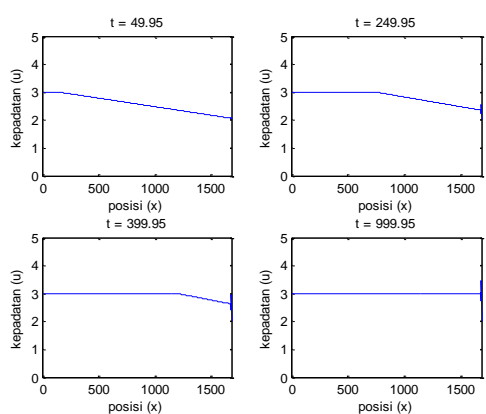

Gambar 11. Simulasi Kasus 3 dengan Waktu yang Berbeda

Dari Gambar 11 tersebut bisa diamati perubahan kepadatan di beberapa waktu. Pada $t$ awal kepadatan kendaraan terjadi di daerah batas kiri, tetapi lama-lama terjadi penumpukan kendaraan sampai ujung interval. Hal ini dikarenakan jumlah kendaraan yang bisa melewati batas kanan hanya 2 kendaraan, sehingga terjadi antrian di sepanjang interval jalan. Pada kasus ketiga ini model yang digunakan adalah model non linier, sehingga kepadatan sepanjang ruas jalan pun akan mengalami fluktuasi pada posisi tertentu. Seperti pada gambar di bawah ini

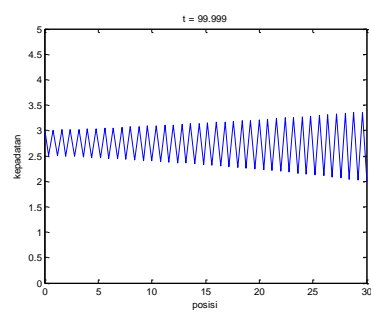

Gambar 12. Fluktuasi Kasus 3 pada $x=10$ 
$u_{x}(0, t)=3$

$u_{x}(1680, t)=2$

$u(x, 0)=\frac{-x}{1680}+3$

Pada Gambar 12 tersebut dapat diketahui bahwa pada saat $0<x<30$ kepadatan kendaraan sudah mengalami fluktuasi dari awal, hal ini karena model yang digunakan adalah model non linier yang bergantung pada kecepatan dan kepadatan kendaraan.

Simulasi keempat dilakukan pada model yang sama dengan kasus ketiga di atas, yaitu dengan model non linier. Akan tetapi kondisi batas yang digunakan berbalik, yaitu posisi $x=0$ terdapat 2 kendaraan dan posisi $x=1680$ terdapat 3 kendaraan. Dengan langkah-langkah yang sama dengan kasus ketiga maka didapatkan hubungan kepadatan berdasarkan ruang dan waktunya sebagai berikut

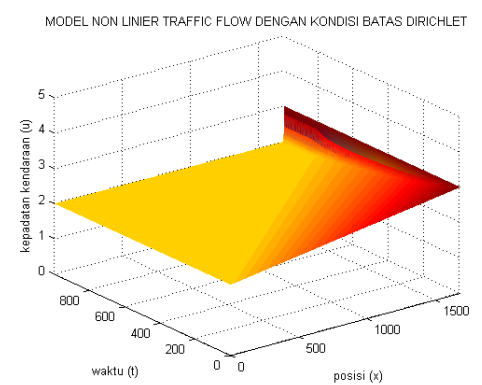

Gambar 13. Simulasi Kasus 4

Pada kasus keempat ini kepadatan lebih fluktuatif. Dapat dilihat dari gambar tersebut bahwa fluktuasi kepadatan sudah terjadi saat $x=$ 3. Tetapi kepadatan kendaraan terjadi ujung jalan karena adanya penumpukan kendaraan di ujung interval jalan. Lebih jelasnya bisa dilihat pada gambar di bawah ini
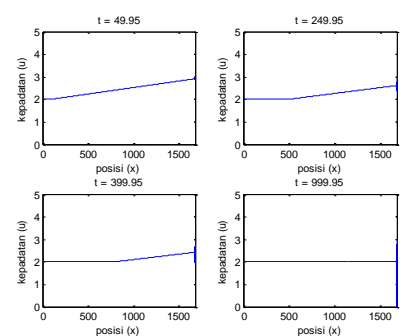
Gambar 14. Simulasi Kasus 4 dengan Waktu
Berbeda

Selanjutnya bila diasumsikan pada posisi $x=0$ terdapat 3 kendaraan yang masuk pada interval, dan pada $x=1680$ terdapat 2 kendaraan yang keluar pada interval, maka persamaan (4.10) beserta kondisi batasnya dapat dituliskan sebagai berikut

dengan kondisi

$$
u_{t}+u u_{x}=0
$$

Sedangkan bila kita mendiskritkan kondisi batas (14) dan (15) dengan menggunakan skema beda pusat menjadi:

$$
\begin{array}{cc}
\text { untuk } j=1 \quad \frac{u_{j+1}^{n}-u_{j-1}^{n}}{2 \Delta x} & =3 \\
\frac{u_{2}^{n}-u_{0}^{n}}{2 \Delta x} & =3 \\
u_{0}^{n}=u_{2}^{n}-6 \Delta x &
\end{array}
$$

Dan untuk batas kanan

$$
\begin{aligned}
& \text { Untuk } j=l \\
& \qquad \frac{u_{l+1}^{n}-u_{l-1}^{n}}{2 \Delta x}=2 \\
& u_{l+1}^{n}=4 \Delta x+u_{l-1}^{n}
\end{aligned}
$$$$
\frac{u_{j+1}^{n}-u_{j-1}^{n}}{2 \Delta x}=2
$$

Sehingga bila kita substitusikan (16) dan (17) ke skema (13) akan didapatkan kondisi batas kiri sebagai berikut

$$
\begin{gathered}
u_{1}^{n+1}=u_{1}^{n}-\frac{\Delta t}{2 \Delta x}\left(u_{1}^{n}\left[u_{2}^{n}-u_{0}^{n}\right]\right)+\frac{\Delta t^{2}}{4 \Delta x^{2}}\left(u _ { 1 } ^ { n } \left[u_{2}^{n}-\right.\right. \\
\left.\left.u_{0}^{n}\right]^{2}\right)+\frac{\Delta t^{2}}{2 \Delta x^{2}}\left(\left(u_{1}^{n}\right)^{2}\left[u_{2}^{n}-2 u_{1}^{n}+u_{0}^{n}\right]\right) \\
u_{1}^{n+1}=u_{1}^{n}-\frac{\Delta t}{2 \Delta x}\left(u_{1}^{n}\left[u_{2}^{n}-u_{2}^{n}+6 \Delta x\right]\right)+ \\
\frac{\Delta t^{2}}{4 \Delta x^{2}}\left(u_{1}^{n}\left[u_{2}^{n}-u_{2}^{n}+6 \Delta x\right]^{2}\right)+ \\
\frac{\Delta t^{2}}{2 \Delta x^{2}}\left(\left(u_{1}^{n}\right)^{2}\left[u_{2}^{n}-2 u_{1}^{n}+u_{2}^{n}+6 \Delta x\right]\right) \\
u_{1}^{n+1}=u_{1}^{n}-\frac{\Delta t}{2 \Delta x}\left(u_{1}^{n}[6 \Delta x]\right)+\frac{\Delta t^{2}}{4 \Delta x^{2}}\left(u_{1}^{n}[6 \Delta x]^{2}\right)+ \\
\frac{\Delta t^{2}}{2 \Delta x^{2}}\left(\left(u_{1}^{n}\right)^{2}\left[2 u_{2}^{n}-2 u_{1}^{n}+6 \Delta x\right]\right)
\end{gathered}
$$

dan kondisi batas kanan sebagai berikut

$$
\begin{aligned}
u_{l}^{n+1}= & u_{l}^{n}-\frac{\Delta t}{2 \Delta x}\left(u_{l}^{n}\left[u_{l+1}^{n}-u_{l-1}^{n}\right]\right)+ \\
& \frac{\Delta t^{2}}{4 \Delta x^{2}}\left(u_{l}^{n}\left[u_{l+1}^{n}-u_{l-1}^{n}\right]^{2}\right)+ \\
& \frac{\Delta t^{2}}{2 \Delta x^{2}}\left(\left(u_{l}^{n}\right)^{2}\left[u_{l+1}^{n}-2 u_{l}^{n}+u_{l-1}^{n}\right]\right) \\
u_{l}^{n+1}= & u_{l}^{n}-\frac{\Delta t}{2 \Delta x}\left(u_{l}^{n}\left[4 \Delta x+u_{l-1}^{n}-u_{l-1}^{n}\right]\right)+ \\
& \frac{\Delta t^{2}}{4 \Delta x^{2}}\left(u_{l}^{n}\left[4 \Delta x+u_{l-1}^{n}-u_{l-1}^{n}\right]^{2}\right)+ \\
& \frac{\Delta t^{2}}{2 \Delta x^{2}}\left(\left(u_{l}^{n}\right)^{2}\left[4 \Delta x+u_{l-1}^{n}-2 u_{l}^{n}+u_{l-1}^{n}\right]\right) \\
u_{l}^{n+1}= & u_{l}^{n}-\frac{\Delta t}{2 \Delta x}\left(u_{l}^{n}[4 \Delta x]\right)+\frac{\Delta t^{2}}{4 \Delta x^{2}}\left(u_{l}^{n}[4 \Delta x]^{2}\right)+ \\
& \frac{\Delta t^{2}}{2 \Delta x^{2}}\left(\left(u_{l}^{n}\right)^{2}\left[4 \Delta x+2 u_{l-1}^{n}-2 u_{l}^{n}\right]\right)
\end{aligned}
$$


Simulasi untuk kasus kelima ini dilakukan untuk model non linier dengan batas Neuman. Dengan cara yang sama dengan kasus sebelumnya maka didapatkan bentuk grafik kepadatan berdasarkan ruang dan waktu adalah sebagai berikut

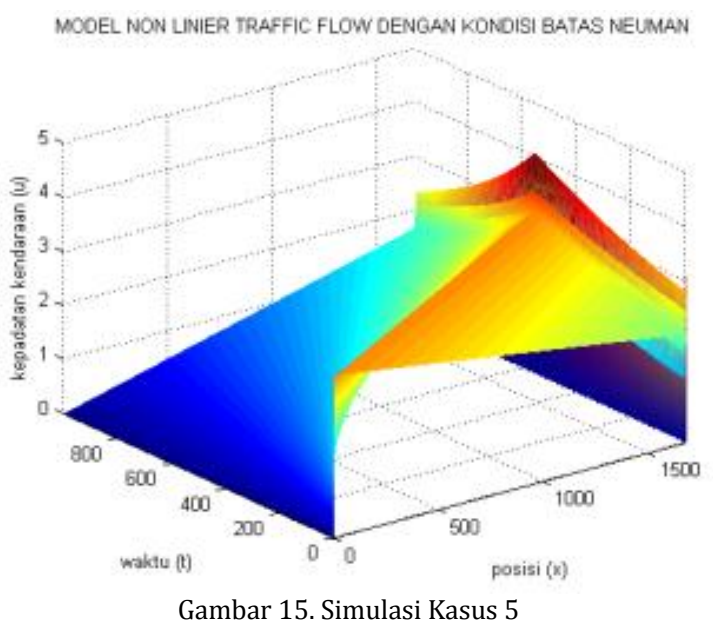

Dari Gambar 15 di atas dapat dilihat bahwa penumpukan kendaraan terjadi di waktu pertama. Setelah $t$ waktu kemudian kepadatan menurun. Artinya berdasarkan model ini jalan bisa dikatakan sepi. Penumpukan jumlah kendaraan terjadi ujung interval yang menyebabkan kepadatan di ujung mencapai 4 kendaraan persatuan luas. Hal ini menunjukkan di ujung jalan terjadi kemacetan yang parah. Berikut disajikan grafik pada beberapa waktu pengamatan yang berbeda
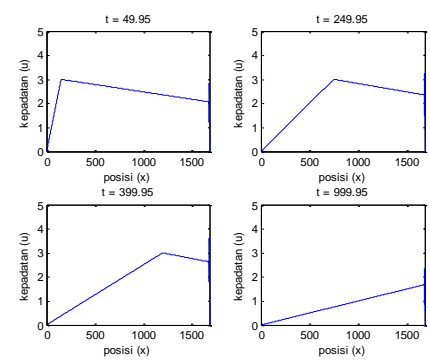

Gambar 16. Simulasi Kasus 5 dengan Waktu Berbeda

Gambar 16 di atas menunjukkan kondisi jalan di beberapa waktu yang berbeda. Dari beberapa posisi yang diamati, dapat diketahui bahwa pada waktu mula-mula kepadatan kendaraan sangatlah tinggi, akan tetapi, lamalama kepadatannya menurun meski terjadi fluktuasi sepanjang interval jalan.

Simulasi keenam adalah simulasi yang dilakukan dengan model yang sama dengan simulasi kelima. Yaitu dengan menggunakan persamaan burger dan kondisi batas Neumann. Akan tetapi kondisi batas yang dipakai berkebalikan dengan simulasi sebelumnya.
Persamaan beserta kondisi batasnya adalah sebagai berikut

dengan kondisi

$$
u_{t}+u u_{x}=0
$$

$$
\begin{aligned}
& u_{x}(0, t)=2 \\
& u_{x}(1680, t)=3 \\
& u(x, 0)=\frac{x}{1680}+2
\end{aligned}
$$

Dengan cara yang sama dengan kasus kelima, maka didapatkan kondisi batas kiri

$$
\begin{gathered}
u_{1}^{n+1}=u_{1}^{n}-\frac{\Delta t}{2 \Delta x}\left(u_{1}^{n}[4 \Delta x]\right)+\frac{\Delta t^{2}}{4 \Delta x^{2}}\left(u_{1}^{n}[4 \Delta x]^{2}\right)+ \\
\frac{\Delta t^{2}}{2 \Delta x^{2}}\left(\left(u_{1}^{n}\right)^{2}\left[2 u_{2}^{n}-2 u_{1}^{n}+4 \Delta x\right]\right)
\end{gathered}
$$

dan kondisi batas kanan sebagai berikut

$$
\begin{aligned}
u_{l}^{n+1}= & u_{l}^{n}-\frac{\Delta t}{2 \Delta x}\left(u_{l}^{n}[6 \Delta x]\right)+\frac{\Delta t^{2}}{4 \Delta x^{2}}\left(u_{l}^{n}[6 \Delta x]^{2}\right)+ \\
& \frac{\Delta t^{2}}{2 \Delta x^{2}}\left(\left(u_{l}^{n}\right)^{2}\left[6 \Delta x+2 u_{l-1}^{n}-2 u_{l}^{n}\right]\right)
\end{aligned}
$$

Sehingga hasil simulasi dengan menggunakan MATLAB sebagai berikut

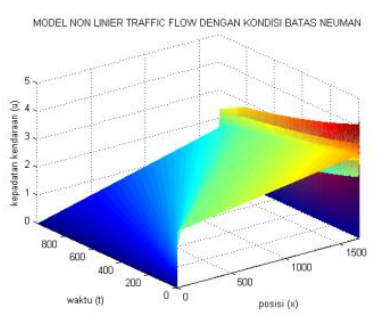

Gambar 17. Simulasi Kasus 6

Grafik yang dihasilkan tidak jauh berbeda dengan kasus kelima. Keduanya memiliki kepadatan di waktu yang pertama dan kemudian kepadatannya menurun setelah $t$ waktu. Sehingga bisa dikatakan untuk model non linier dengan batas Neumann kepadatan kendaraan di sepanjang ruas jalan rendah (tidak ada kemacetan), sehingga memungkinkan para pengemudi untuk memaksimalkan kecepatan kendaraannya. Untuk perubahan kepadatan per satuan waktu bisa dilihat dari gambar berikut 

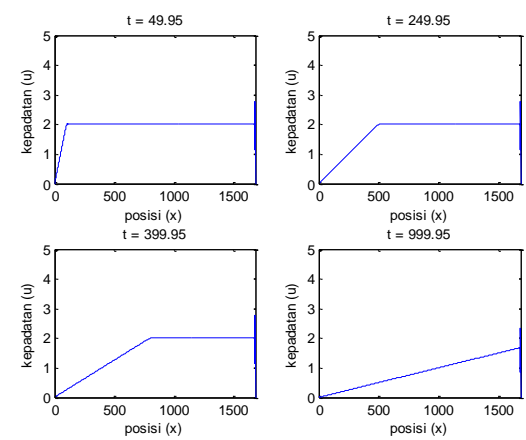

Gambar 18. Simulasi Kasus 6 dengan Waktu Berbeda

\section{PENUTUP}

Berdasarkan pembahasan di atas dapat disimpulkan bahwa model traffic flow yang diturunkan dari hukum-hukum kesetimbangan adalah sebagai berikut

$$
\frac{\partial \rho}{\partial t}+\frac{\partial(\rho v)}{\partial x}=0
$$

dimana $\rho$ menyatakan kepadatan kendaraan, $v$ merupakan kecepatan kendaraan. Bila kecepatan $v$ dalam model tersebut adalah konstan, maka model traffic flow tersebut menjadi persamaan Transport (linier)

$$
\rho_{t}+v \rho_{x}=0
$$

Sedangkan bila kecepatan $v$ merupakan suatu fungsi yang bergantung pada kepadatan kendaraan di setiap $\Delta \boldsymbol{x}$ nya maka model tersebut menjadi persamaan Burger (tansport non linier), dan dapat dituliskan sebagai

$$
u+u u_{x}=0
$$

Sedangkan untuk mencari solusi dari kedua model yang telah dihasilkan, dilakukan dengan menggunakan metode beda hingga skema FTBS untuk persamaan transport, dan metode lax wendroff skema FTCS untuk persamaan Burger. Berdasarkan hasil solusi numeriknya dapat diketahui bahwa model linier tersebut stabil dengan syarat $0 \leq v \frac{\Delta t}{\Delta x} \leq 1$, sedangkan model non liniernya stabil bila dilihat dari grafiknya, akan tetapi perlu adanya analisis konvergensi untuk mengetahui kestabilan dan kekonsistenan dari model non linier tersebut.

\section{DAFTAR PUSTAKA}

[1] K. Nagel, "Particle hopping vs. fluiddynamical models for traffic flow," $L A U R, \mathrm{p}$. 4018, 1995.

[2] D. S. \& J. LV, "In-Depth Analysis of Traffic Congestion using Computational Fluid Dynamic (CFD) Modelling Method," J. Mod. Transp., vol. 19, no. 1, pp. 58-67, 2011.
[3] C. F. Daganzo, "Requiem for second-order fluid approximations of traffic flow," Transp. Res. Part B Methodol., vol. 29, pp. 277-286, 1995.

[4] A. Aw and M. Rascle, "Resurrection of 'Second Order' Models of Traffic Flow," SIAM Journal on Applied Mathematics, vol. 60. pp. 916-938, 2000.

[5] G. Whitham, Linier and Non Linier Waves. Canada: A WILEV-IMTERSCIENCE SERIES, 1974.

[6] Immers dan Logghe, Traffic Flow Theory, no. May. Heverlee Belgium: A WILEVIMTERSCIENCE SERIES, 2002.

[7] R. M. Olson, Dasar Dasar Mekanika Fluida Teknik. 1993.

[8] A. Jungel, "Modeling and Numerical Approximation of Traffic Flow Problems," 2002. 